\title{
The Territorial Select Committees, 40 Years On
}

\author{
David Torrance ${ }^{1}$ and Adam Evans ${ }^{2, *}$ \\ ${ }^{1}$ House of Commons Library, House of Commons, London, UK; \\ ${ }^{2}$ House of Commons, London; \\ ${ }^{3}$ Wales Governance Centre, School of Law and Politics, Cardiff University, Cardiff, UK \\ *Correspondence: EvansAB@parliament.uk
}

The territorial departmental select committees have largely escaped academic scrutiny since their establishment in 1979 (for Scotland and Wales) and 1994 (Northern Ireland). This article charts the history of territorial representation in Westminster, including the creation of grand committees for Scotland and Wales and a Northern Ireland Standing Committee, before explaining the forces that led to the creation of territorial departmental select committees. The article then explores the work of these committees after their formation, and explores how they have responded to the devolution dispensations in their respective nations. A key theme of this article is the influence of constitutional developments in Scotland, Wales and Northern Ireland on territorial committees at Westminster. Indeed, as this article highlights, the different timings of establishment, the asymmetric levels of (in)stability in the various devolution dispensations and prolonged suspensions of devolution in Northern Ireland have had an impact on the role of the respective territorial select committees.

Keywords: Devolution, British politics, Constitutional history, Parliament, Select committees

\section{Introduction}

This article focuses on a branch of the select committee system that has largely escaped academic scrutiny: namely, the three 'territorial' select committees. While the Procedure Committee's 1978 report did not include Scotland, Wales or Northern Ireland in its recommendations for departmental select committees, territorial select committees have been in existence (at least for Scotland and Wales) since the departmental committee system came into existence in 1979. ${ }^{1}$

\footnotetext{
${ }^{1}$ Scotland also had an 'experimental' committee in the late 1960s and the early 1970s.
} 
We look at the history of territorial representation at Westminster and the factors leading to the creation of territorial select committees for Scotland and Wales in 1979, before turning to the work of the Scottish and Welsh Affairs Select Committees between 1979 and 1997, when Labour was elected on a manifesto, including referendums on devolution in Scotland and Wales. We will then explain the formation of a NIAC in 1994, before assessing the work of the territorial select committees since 1998. A key theme is the influence of constitutional developments in Scotland, Wales and Northern Ireland on territorial committees at Westminster.

\section{The history of territorial representation in Westminster}

\subsection{Scotland}

Just as the creation of a Scottish Office and associated minister in 1885 set a precedent for the UK government's handling of territorial governance, the Scottish Grand Committee (SGC) introduced a territorial element into parliamentary business upon its creation in 1894 . After abolition by the Conservatives, it was reestablished on a permanent basis when the Liberals returned to office in 1906 (Mitchell, 2014).

As debates regarding Scottish 'home rule' or devolution gathered momentum after the 1930s, reforms to the SGC were regularly mooted in response. In 1948, Attlee's Labour government promised an alteration to its standing orders to allow the 'general principles' of Scottish Bills to be considered by the Committee, while after 1957 it was also allowed to debate general 'matters' of interest to Scotland; the Committee Stage was transferred to a smaller Scottish Standing Committee (to which a second was added in 1968). ${ }^{2}$ As part of the 1948 reforms, six sittings of the SGC were also allowed for discussion of Scottish Estimates, which increased to eight in 1957. It was, judged by Edwards (1971, p. 322), the 'only institution which even vaguely resembles a Scottish Parliament'.

Burns (1960) considered the SGC 'an interesting legislative experiment', which was augmented by another in February 1969, when a committee to consider 'Scottish Affairs' was established, the brainchild of then Leader of the House, Richard Crossman. It replaced a Select Committee on Agriculture, which was abolished having upset the Labour government with its probing. But the Scottish Affairs Committee (SAC) was, observed Mackintosh (1970, p. 37), 'appointed not to meet any demand among MPs but to try and ease outside political pressures', those 'pressures' being the electoral rise of the Scottish National Party (SNP).

\footnotetext{
${ }^{2}$ The two Scottish Standing Committees comprised between 16 and 50 MPs, of whom not less than 16 were required to represent Scottish constituencies.
} 
Myers (1974, p. 359) suggested other justifications: that it would be less controversial than Agriculture, that Labour had a good record in Scotland, and the need to occupy non-ministerial Scottish Labour MPs. The committee's initial membership proved controversial, so John P. Mackintosh, a known prodevolutionist, was added. Until 1970, there were 16 members, including a Liberal and SNP representative, but thereafter (1970-1972), 14 members, all of whom were Labour or Conservative MPs.

The SAC published just two reports, Economic Planning in Scotland (19691970) and Land Resource Use in Scotland (1971-1972), which Myers (1974) reckoned both had 'little influence' on the formulation of public policy beyond providing 'useful reference material'. Public attendance, meanwhile, was 'sporadic', and media attention waned once the initial novelty had worn off. And once both main parties 'recovered from the fright of the Hamilton bye-election and the growth of political nationalism in Scotland they no longer saw the Committee as serving any real political purpose' (Myers, 1974, pp. 368-369).

On 30 November 1972, James Prior, Conservative Leader of the House, said that he was considering whether to reconstitute the SAC during the 1972-1973 session, but did not. There were, added Myers (1974, p. 370), 'very few mourners', while following the SNP's breakthrough in the two general elections of 1974, Berridge and Kellas (1973, p. 29) doubted 'whether Parliamentary remedies alone were now sufficient' as a response to political nationalism in Scotland.

\subsection{Wales}

As in Scotland, moves for a Welsh voice at Westminster also materialised in the late 19th century, the formation of a Welsh Parliamentary Party in 1888 and of Cymry Fydd in 1886 providing a vehicle for the 'quasi-nationalist tendencies seen within Welsh Liberalism' (Griffith, 2006, pp. 94-100), albeit one that lost momentum in the early 1890s before stalling entirely in 1896 (Davies, 2007, pp. 452-453).

During an extended debate on the establishment of standing committees in March 1888, the Liberal MP for Arfon, William Rathbone, unsuccessfully moved an amendment calling for a Grand Committee for Wales and Monmouthshire (HC Deb 7 March 1888, vol. 323 c469). A further bid for a Welsh Grand Committee was made in the mid-1890s by Welsh Liberal MPs keen to imitate moves by their Scottish colleagues (Griffith, 2006, p. 110). Again, this failed to shift opinion within Westminster.

In 1907, in the wake of similar provision being made for Scotland, the House of Commons amended its standing orders so that bills relating exclusively to Wales could have their committee stages in a standing committee consisting of Welsh members (Jones, 1990, p. 221). However, as Barry Jones and Wilford 
(1986, p. 7) have noted, this innovation had little impact as 'very few Bills relate exclusively to Wales'.

It took another 50 years for demands for a committee to yield fruit. In 1958, Ness Edwards, the Labour MP for Caerphilly, submitted a memorandum to, and gave oral evidence before, the House of Commons' Procedure Committee. Although a day's debate per session had been set aside for Welsh Affairs in 1944, Edwards suggested that the Chamber was 'not the proper place' to discuss purely Welsh or Scottish matters. Instead, Edwards called for a Welsh Grand Committee based on the Scottish model to be established (Procedure Committee, 1959, pp. 131-132).

Edward's proposal was accepted by the Procedure Committee in its 1959 report (Procedure Committee, 1959, paragraphs 48 and 59), endorsed by the Conservative government in February 1960, and created following a Commons resolution on 5 April 1960. According to Barry Jones and Wilford (1986, p. 9), its track record was not 'particularly inspiring', and by 1966 Ness Edwards was calling it to be reformed along the lines of a select committee (HC Deb 17 May 1966, vol. 728 cc227-8W), although that would take another 13 years to materialise.

\subsection{Ireland/Northern Ireland}

An Irish Grand Committee had been mooted in 1882 and 1884 by, among others, the Irish Parliamentary Party leader Charles Stewart Parnell, although such calls were resisted by then Prime Minister W. E. Gladstone. In an 1895 debate on a standing committee for Scotland, Gerald Balfour told MPs that

neither Party could afford to send a contentious Irish measure to an Irish Grand Committee, because such a measure would be certain to leave the Committee in a form that would fail to recommend itself to any other section of the House ... though such an arrangement might mean a gain to local interests, it would undoubtedly mean a serious loss to National unity (HC Deb 9 May 1895, vol. 33 c837).

The apparent settlement of the Irish question after 1921 removed such pressure, and it was only in 1975-following the prorogation and subsequent abolition of Stormont - that a Northern Ireland Committee (NIC), a standing committee of the House, was constituted on 10 February 1975. Comprising all Northern Ireland MPs plus not more than 20 others nominated by the Committee of Selection, the NIC had the power to consider matters relating exclusively to Northern Ireland.

To the general deliberative function of the NIC was soon added an informal legislative component, chiefly pre-parliamentary consultation on Orders in Council, by which Northern Ireland was largely governed under direct rule. 
While this gave the NIC considerable potential, Hadfield's (1981, p. 208) judgement in 1981 was that it had 'not so far been fulfilled', with only a minority of orders reaching its members for consideration.

Being a standing committee, the NIC lacked the wider remit of a select committee to send for persons, papers and records, conduct inquiries and make reports; its only other function was annual consideration of reports from the Northern Ireland Examiner of Statutory Rules. Thus, Hadfield (1981) recommended the creation of a select committee, although in 1978 the Procedure Committee 'intentionally excluded specific reference to [Welsh, Scottish and Northern Ireland affairs] in view of the uncertainty about the future form of government for Wales, Scotland, and Northern Ireland' (Procedure Committee, 1978, paragraph 5.25).

\section{Territorial select committees, 1979-1999}

The Select Committee structure introduced in 1979 dealt with the three nonEnglish parts of the UK's territory in different ways, reviving the 'experimental' SAC of the late 1960s and the early 1970s, creating a Welsh equivalent for the first time, and kicking a Northern Ireland affairs committee into the long grass.

The new Prime Minister, Margaret Thatcher, was unhappy about departmental select committees in general and one covering Northern Ireland in particular (Aylett, 2015, pp. 206-207). Initially, her Leader of the House, Norman St John Stevas attempted to hold the Scottish committee in 'reserve', to be produced following all-party talks on Scottish governance, ${ }^{3}$ although it ended up being 'smoked out' before then (Dewar, 1980, p. 8), with the Commons agreeing to its appointment on 31 October 1979. Members of both the Scottish and the Welsh Committees were agreed by the House less than a month later, although neither began work until early 1980 .

Dewar was quite clear that the SAC, of which he became the first chair, was 'not a form of devolution', although it inevitably came to be seen as a proxy for the failed Scottish Assembly, and for symbolic reasons it met early on at the Old Royal High School in Edinburgh, until recently earmarked (and refitted) for that Assembly, while the Welsh Affairs Committee (WAC) convened at Cardiff Castle, where Leo Abse, its flamboyant chair, declared that it signalled an end to 'mandarin government' (Dewar, 1980, p. 24).

\subsection{SAC}

The SAC continued a long tradition of ways of managing Scottish business at Westminster. Its remit was 'to examine the expenditure, administration and

\footnotetext{
${ }^{3}$ The all-party talks took place in 1980 and led to minor changes in the operation of the Scottish Grand Committee, which thereafter was allowed to meet in Edinburgh, having been shorn of non-Scottish members and equipped with more days to debate 'matters' of Scottish interest.
} 
policy of the Scottish Office and associated public bodies'. In doing so, the committee met frequently in Scotland and abroad. It was chaired by a Labour member, which reflected that party's predominance north of the border (although there remained an in-built Conservative majority). Following an initial inquiry into inward investment, the SAC generally pursued less controversial subjects. Even so, it tended to be quite tribal (neither of the SNP's two MPs in the 19791983 Parliament chose to serve). Drucker and Kellas (1985, p. 231) critiqued the Committee's 'high turnover of members and chairmen; a poor adviser-member relationship; excessive size and lack of sub-committees; and its subject-matter has lacked cohesion'.

Initially, as in 1969, the Scottish media fully covered SAC meetings before losing interest, especially once journalists realised that it would not rekindle the constitutional debate or become a de facto Scottish Assembly. 'It met in a blaze of television cameras at the Scottish Land Court', observed Dewar, 'and then hardly impinged on public consciousness at all' (Dewar, 1980, p. 17). Nevertheless, the SAC possessed an 'assured place' as part of the 'Scottish Lobby'. 'The Scottish Affairs Committee (like the Welsh) is speaking for a nation' observed Drucker and Kellas, 'in the context of a system of committees which was designed to speak for Parliament' (Drucker and Kellas, 1985, p. 235).

The general election of 1987, at which the Conservatives lost all but 10 of their Scottish seats, brought long-standing tensions over the political balance of the SAC to a head. Not only did the depleted Scottish Conservative benches make finding enough members able or willing to serve difficult, but Labour also demanded a majority and said it would not accept MPs from non-Scottish constituencies. As a result, the SAC did not meet at all during the 1987-1992 Parliament, although an unofficial 'Alternative Committee' comprising opposition Scottish MPs was formed in December 1988, producing one report the following year (McConnell and Pyper, 1994). Only after the 1992 election was the SAC revived as part of a wider effort by John Major to address the pressure for devolution-which included extensive revisions of the powers of the SGC as well. ${ }^{4}$ Both main parties compromised Scottish Conservative backbenchers who agreed to serve on a smaller committee of 11 (rather than 13) members, while Labour accepted both non-Scottish MPs and Scottish Conservatives who were also serving as Parliamentary Private Secretaries (PPSs) (McConnell and Pyper, 1994).

\footnotetext{
${ }^{4}$ The Conservative Government's 'Taking Stock' exercise after the 1992 election, focused on the powers of the SGC, which were (as in 1948 and 1957) again extended; Scottish Secretary Michael Forsyth even proposed allowing majority votes in the SGC to be binding, although this did not win Cabinet approval (Torrance, 2006, p. 332). The SNP, meanwhile, targeted the Scottish Standing Committee as part of its occasional disruption of Parliamentary proceedings (Torrance, 2010).
} 
Despite continuing tensions underscored by growing demands for legislative devolution, the revived SAC sustained a relatively high profile during the 19921997 Parliament. Its drug abuse inquiry was widely seen by members as its 'finest hour', attracting a great deal of press attention, as did a highly charged televised evidence session with Scottish Office Minister Lord Fraser regarding the Peterken-Fyfe affair about the sacking of a senior National Health Service official (McConnell and Pyper, 1996).

In assessing the revived Committee's effectiveness, McConnell and Pyper were 'in no doubt that its record compares very favourably with that of its predecessors', although this was

not to deny the fact that the committee is beset by numerous problems. Its membership abounds with PPSs, there are pressures for members to devote less and less time to it, it has backed away from investigating and producing reports on some highly politically sensitive issues, and a fragile consensus is constantly in danger of being undermined by the vagaries of Scottish politics (McConnell and Pyper 1996).

\subsection{WAC}

In the closing weeks of the 1979 referendum campaign, a parliamentary committee had been mooted as a possible alternative to a Welsh Assembly, and indeed the repeal of the Wales Act 1978 and the motion establishing WAC was later debated on the same day. 'Clearly the Assembly is dead - rejected decisively on St David's Day', remarked one Labour backbencher. 'Now long live the Select Committee' (Barry Jones, 1985, p. 289).

Although several anti-devolution Labour MPs ended up on the new 11-strong committee, when established in 1979 it was perceived by some as a 'surrogate for the lost Assembly' and 'invested with an important symbolic value', although from the Conservative government's point of view this was 'of secondary importance' (Barry Jones and Wilford, 1986, p. 11). Of the Conservatives' 11 Welsh MPs, the six non-ministers constituted a majority on the committee, which, like its Scottish equivalent, was chaired by a Labour Member.

It was the last of the new select committees to come into operation and held its first public session on 10 March 1980. Like its Scottish counterpart, the WAC was simultaneously a 'specialist' and a 'national' committee, possessing, according to Barry Jones and Wilford, 'two mandates'. As a result, it was obliged to address two audiences, one parliamentary and the other popular, 'and to pitch its performance to ensure that while placating one it does not alienate the other' (Barry Jones and Wilford, 1986, p. 76).

The Janus-like character of WAC was sustained even by its anti-devolution members, who were keen to appear sensitive to the Welsh dimension in order to 
demonstrate the committee's viability as an alternative to legislative devolution. To this end, its first two meetings were held in Wales (although generally in London thereafter), while on 16 February 1981 part of its proceedings were conducted in Welsh, the first time a non-English language had been used in formal parliamentary proceedings (Barry Jones, 1985, p. 296).

But while Barry Jones reckoned that WAC did evolve a 'viable role' (as well as a more consensual character than its Scottish equivalent) it was 'not as an alternative to the assembly' (Barry Jones, 1985, p. 302). On the other hand, it had developed 'a key co-ordinating role' and 'a more clearly defined Welsh dimension to political debate', meaning that WAC had 'fulfilled its territorial remit' (Barry Jones and Wilford, 1986, pp. 82 and 88).

\subsection{NIAC}

As recounted earlier, Northern Ireland was excluded from the 1979 reforms, largely on grounds of political sensitivity, so between then and 1997 Northern Ireland experienced what Wilford and Elliott called a 'yawning deficit in Parliamentary accountability occasioned by direct rule'; only on five occasions did another specialist select committee investigate specific Northern Irish matters (Wilford and Elliott 1999, pp. 23 and 25), despite an exhortation by the then Clerk of Committees to Committee Clerks to encourage such ventures. The Northern Ireland Standing Committee formed in 1975, meanwhile, lapsed after 1985 when it was boycotted by Ulster Unionist MPs in opposition to the AngloIrish Agreement (Birrell, 2009, p. 56).

In 1990, the Procedure Committee concluded that the reasons for Northern Ireland's exclusion in 1978-1979 no longer held and argued 'for bringing the Northern Ireland Office formally within the system of scrutiny by Select Committees' (Second Report of the Procedure Committee 1989-1990 HC 19-I, paragraph 278). The Ulster Unionist Party broadly agreed and entered covert negotiations with John Major's Conservative government, with plans for a new NIAC announced shortly after the 'Downing Street Declaration' in December 1993.

Although provision was made for each of the Northern Irish parties to have a place on the 13-member NIAC, in accordance with normal practice-and precedent on the Scottish and Welsh Committees - the government was to enjoy a majority. Labour and the Social Democratic and Labour Party (SDLP) refused to support the government motion establishing the committee, but it still passed with a majority of 103 (indicating that resistance to the select committee proposal was more rhetorical than substantive, given that the Government's majority was under 20) on 9 March 1994. The next item of business added the word 'Grand' to the Northern Ireland Standing Committee established in 1975 (HC Deb 9 March 1994, vol. 239 cc340-71). 
The NIAC's first chair was Jim Kilfedder, not a mainstream unionist (he had formed the Ulster Popular Unionist Party in 1980) but considered 'safe' by Ulster Unionist leader James Molyneaux and accepted as someone who could operate in a bipartisan manner, given his former role as speaker of the defunct Northern Ireland Assembly. In theory, judged by Wilford and Elliott, the existence of NIAC

brought the scrutiny of the Province's administration and governance fully into the Parliamentary fold; but in practice the Committee was to shy away from matters that could threaten an internal consensus ... In effect, topics that touched on the constitutional affairs of the Province, or which related to reserved matters such as policing or prisons, was placed out of bounds (Wilford and Elliott, 1999, p. 27).

Rather the Committee examined illicit drug use, electricity prices, educational underachievement and planning.

Acting as a constraint upon the NIAC was its creation just as the Northern Ireland peace process entered a new phase; many committee members were involved in the inter-party talks and were therefore reluctant to disrupt its progress. However, few members, from either the province or the mainland, believed that the new committee had made much of an impact, although it had increased awareness of Northern Irish affairs while maintaining relatively amicable interparty relations (Wilford and Elliott, 1999, p. 39).

\section{Territorial select committees, post devolution}

\subsection{The SAC}

Following devolution to Scotland and Wales in July 1999, and its restoration in Northern Ireland at the end of that year, there arose inevitable questions as to the need for a plethora of territorial select, grand and standing committees, particularly when it came to Scotland, to which the most power had been transferred.

The SAC's own view, as expressed in a thoughtful and prescient report on The operation of multi-level democracy, was that it could have a 'valuable role to play' in monitoring the 'process of devolution' and providing a forum in which 'disputes could be aired publicly in a political context' (Scottish Affairs Committee, 1998, paragraph 86).

Thus, the committee would fulfil more of a liaison role, something supported

by the Procedure Committee's inquiry, The Procedural Consequences of Devolution, which reported on 15 April 1999. On 25 October 1999, Standing Order 152 altered the remits of the SAC (together with its Welsh and Northern Irish counterparts) to allow not only scrutiny of each territorial department or office but also of the relations between that office and its corresponding devolved 
administration (HC Deb 25 October 1999, vol. 336 cc775-80). The fact that there was very little change to the territorial committees' structure reflected the minimal change within Whitehall more broadly, with both the Secretary of State for Scotland and the renamed Scottish Office remaining in place.

Hazell (1999, p. 124) of the UCL Constitution Unit had suggested sweeping up the three territorial committees into 'a wider Select Committee on Devolution', something he thought more likely if, in time, a single government department responsible for intergovernmental relations emerged. A 2006 SAC inquiry into the Sewel Convention ${ }^{5}$ also suggested that the Procedure or Modernisation Committees look at a 'Super' SGC, comprising Scottish MPs, MSPs and Scottish MEPs, to discuss (but not decide on) matters of mutual interest (Scottish Affairs Committee, 2006, paragraph 43). Neither suggestion made any discernible impact, much like proposals to create a single constitutional department and associated cabinet minister.

Now that a Scottish Parliament existed in Edinburgh, scrutinising an Executive with extensive competence in domestic policy, there was little need for the SAC to fulfil its proxy devolution (or territorial) role in addition to its modified scrutiny function, and indeed it appeared to find it hard to identify areas for investigation (unlike the Welsh and Northern Irish committees whose territories enjoyed initially less legislative and administrative competence and instability of its devolution regime resulting in sustained periods of direct rule, respectively), leading Masterman and Hazell to conclude it had been 'slow to respond to the post-devolution climate at Westminster' (Masterman and Hazell, 2001, p. 211). Meanwhile, the SGC, once seen as a de facto Scottish Parliament, met infrequently, and less often than its Welsh and Northern Irish counterparts.

Following the election of an SNP Scottish Government in 2007, the dynamic changed, with the SAC_chaired since 2005 by Glasgow Labour MP Mohammad Sarwar-conducting several constitutional inquiries. After the 2011 Holyrood election, as a result of which an independence referendum became inevitable, tensions increased. When the then chair Ian Davidson, another Scottish Labour MP, announced inquiries into the cost of what he called 'separation', 6 the SNP MP

\footnotetext{
${ }^{5}$ The 'Sewel Convention' refers to the commitment, made by the then Minister of State in the Scottish Office, Lord Sewel, that the UK Parliament would 'not normally legislate with regard to devolved matters in Scotland without the consent of the Scottish Parliament'. The Sewel Convention is also understood to apply to legislation affecting the competence of the devolved legislatures. The Convention is underpinned by the memorandum of understandings between the UK government and the devolved legislatures and the UK government's Devolution Guidance Notes as well as being enshrined in the Scotland Act 2016 and Wales Act 2017 (see also Trench, n.d.).

${ }^{6}$ Several reports subsequently appeared under the heading: 'The Referendum on Separation for Scotland'.
} 
Eilidh Whiteford claimed it would be 'a partisan and pejorative inquiry'. At a subsequent committee meeting, Davidson made a remark Whiteford regarded as 'aggressive and threatening' and she later wrote to all committee members saying she would 'withdraw' (but not resign) from SAC for as long as Davidson retained the chair (Gardham 2011).

The dynamic shifted again following the 2015 UK general election, at which the SNP won 56 seats. Given its new status as the third-largest party in the House of Commons, it was entitled to chair two select committees, one of which was Scottish Affairs. There followed a series of topical inquiries, including into English votes for English laws and the devolution of welfare in Scotland, and, reflecting the SAC's post-1999 role, investigations into the relationship between the UK and Scottish Governments and the work of the Office of the Secretary of State for Scotland.

\subsection{The WAC}

As in Scotland, the advent of devolution and the transfer of key functions from the Welsh Office (rebadged after devolution as the Wales Office) to the National Assembly for Wales (NAfW) meant a reduction in the potential scope of inquiry for the Welsh Affairs Select Committee (WAC). However, these horizons had not narrowed as substantially as those for the Scottish Affairs Select Committee, a reflection of the asymmetry in the devolution process.

While most of the Secretary of State for Wales and the Welsh Office's functions, as well as secondary legislative powers, were transferred to the NAfW, primary law-making powers in those devolved fields (and others) remained reserved to Westminster (Rawlings, 2003, pp. 5-6). Because of this separation of primary and secondary legislative responsibilities, and the 'conferred powers' model (in contrast to Scotland's 'reserved powers' model of devolution) underpinning the devolution settlement, there existed a 'jagged edge' devolution boundary and a strong degree of policy and legislative interdependency between Wales and Westminster (Evans, 2019, pp. 102-104).

The WAC's initial approach to devolved life was set out in a special report published in the 2000-2001 session. In this, the committee stressed that it could 'play a useful role in the scrutiny of Welsh legislation and of UK wide (or England and Wales wide) legislation as it affected Wales' and that, while respecting the Assembly's independence, it did not want its remit to be restricted purely to scrutinising the Wales Office (WAC, 2000, paragraphs 5-6). Noting that, postdevolution, its terms of reference had been amended to include the Secretary of State's relations with NAfW, the committee explained that it had 'taken a flexible approach' to interpreting this remit so as to give itself a role to 'examine the impact of UK Government policy in Wales, as well as ... the mechanics of the 
devolution settlement and the calculation of the National Assembly's budget' (WAC, 2000, paragraphs 7-9).

As a result of this approach, and 'the jagged edges' of Welsh devolution, the WAC soon undertook a number of inquiries that involved an examination of the impact of UK Government policies in Wales, as well as some matters which are the responsibility of the National Assembly' (WAC, 2000, paragraph 10), for example, scrutinising social exclusion, as well as the impact of the Transport Bill, in Wales. Unsurprisingly, as early as 2003 there was increasing frustration at the level of duplication of scrutiny work undertaken by WAC and committees of the NAfW' (Evans, 2019, p. 103). These frustrations had been particularly felt in relation to the draft National Health Service (Wales) Bill which had been the subject of pre-legislative scrutiny by both the WAC and the Health and Social Services Committee of NAfW, this experience proved instrumental in prompting WAC to lobby, successfully, for the House of Commons' Standing Orders to be reformed to permit formal joint meetings between it and NAfW committees (Evans, 2019, pp. 103-05).

As the Welsh devolution settlement evolved after 1999, so too did the WAC's workload and remit. In 2006, Parliament passed a second Government of Wales Act (GoWA 2006), increasing the powers of NAfW and providing a two-phase process whereby it could gain primary law-making powers. The first phase, provided for in Part 3 Schedule 5 of GoWA 2006, saw the Assembly able to bid, on a case-by-case basis, for legislative powers in 20 devolved subject fields. These bids, known as Legislative Competence Orders (LCOs), were subjected to prelegislative scrutiny at Westminster and the NAfW, before requiring approval from the Assembly and both Houses of Parliament (Griffiths and Evans, 2013, pp. 484-488).

The result was that the WAC, between 2007 and 2011, played an important role in the pre-legislative scrutiny of LCOs and become a much higher-profile body in Welsh political life than it hard arguably been since 1999. According to Griffiths and Evans, the committee's workload levels 'rose significantly, with 15 reports in 2008-2009 and 11 in the short 2009-2010 session, compared with three in 2006-2007 and five in 2005-2006' (Griffiths and Evans, 2013, p. 503). However, while Griffiths and Evans suggested that the LCO process 'successfully re-engaged both Houses of Parliament, through their select committee, with the devolutionsettlement', 7 they acknowledged that the WAC's role attracted controversy and was 'at times the target of particular criticism for its part in the process' (Griffiths and Evans, 2013, pp. 504-505). The LCO era ended in 2011 after a

\footnotetext{
${ }^{7}$ Including some attempts by WAC to use its power to meet jointly with NAfW committees, albeit the drive for joint working was often frustrated by draft LCOs not being introduced simultaneously in Cardiff and Westminster (Griffiths and Evans 2013, p. 502).
} 
referendum on further powers for the Welsh Assembly was won by a two-to-one margin (64-36\%). The referendum result saw the NAfW move to the second phase of the two-step journey to legislative powers outlined in GoWA 2006 (moving from Part 3 Schedule 5 to Part 4 Schedule 7), enjoying primary legislative powers in the 20 devolved subject fields.

Again, as the Assembly's powers evolved, so too did the WAC's remit. With the pre-legislative scrutiny inquiries into draft LCOs a thing of the past, the number of reports produced by WAC fell over the course of the 2010-2015 Parliament: during the (longer than usual) 2010-2012 session, the committee published eight reports, but in the 2012-2013 session this number dropped to three, with four reports in the 2013-2014 and 2014-2015 sessions. Nonetheless, the distinctively 'jagged' nature of the Welsh devolution settlement, and its limits when compared to Scotland (even after the 2011 referendum), continued to offer the WAC scope to inquire into areas that would not otherwise be within the remit of other territorial committees, e.g. inquiries into the prison service in Wales and shale energy-both of which touched on areas that were reserved to Westminster, yet intersected with devolved responsibilities.

\subsection{The Northern Irish Affairs Committee}

Strand One of the 1998 Belfast Agreement stated that Westminster would continue to 'scrutinise, including through the Northern Ireland Grand and Select Committees, the responsibilities of the Secretary of State' (Belfast Agreement, 1998, paragraph 33), any amendment to which would require revision of the Agreement. Thus, NIAC's scrutiny role was statutory as well as underpinned by Commons' standing orders.

The Northern Ireland Grand Committee (NIGC) also remained active, initially focusing on reserved/excepted orders in council but also handling devolved areas when Stormont was suspended between 2002 and 2007. It held debates and questioned ministers regularly after 1998, and even more frequently after 2002. Unionist MPs complained about the NIGC not meeting in Northern Ireland itself, so it started convening in Belfast (Birrell, 2009, p. 56). It last met in 2013.

In the 1997 Parliament, meanwhile, the Conservative MP Sir Peter Brooke emerged as chairman of a Labour-majority Committee. With Northern Ireland experiencing a high profile and devolution pending to a power-sharing Assembly and Executive in Belfast, the safety-first approach of old would have been difficult to sustain. Sir Peter even stated in a press release that NIAC would 'not shy away from controversy' and embarked upon inquiries into the Royal Ulster Constabulary, electoral malpractice and the prison service, all subjects within 'reserved' or 'excepted' areas - that is to say where legislative competence is reserved to Westminster (Wilford and Elliott, 1999, p. 41). 
The ongoing peace process became a continuing theme of NIAC's work after 1999 (power was transferred to the Assembly and Executive in December that year), while it (like the NIGC) tended to be more active during periods in which devolution was suspended, producing, for example, 30 reports between 2002 and 2007, and even establishing a sub-committee with a different chair to consider matters previously dealt with by the Assembly, although this later lapsed. Osborne (2002) believed the NIAC suffered from a lack of Northern Irish members with local knowledge and interest.

Although the NIAC was able to handle pre-legislative scrutiny, it rarely pursued this function, an exception being a Policing Bill; until 2009, around twothirds of the subjects it investigated fell within the remit of the Northern Ireland Office. In 2014-2015, the NIAC produced a major report regarding 'on the runs', while since 2016 Brexit has loomed large. After 2017, when the Northern Ireland Assembly and Executive collapsed, the committee (as between 2002 and 2007) took on inquiries in devolved areas, such as health and education funding, while in 2018 it produced a report on the collapse of the devolved institutions.

Electoral changes in Northern Ireland also meant the committee's membership was narrower than in the mid-1990s, with no Nationalist representation, given the decline of the SDLP and the continuing abstentionist policy of Sinn Féin. Since 2010, it has been chaired by Conservative MPs from mainland constituencies, unlike its Scottish and Welsh counterparts, which have usually been convened by Scottish and Welsh members, respectively.

\subsection{England: an experiment in territorial recognition on the Committee corridor?}

Prompted by the Brown administration's The Governance of Britain Green Paper in 2007, the Select Committee on Modernisation of the House of Commons published a report in 2008 which proposed the creation of select, and grand, committees as a means of plugging the regional accountability gap in England (Modernisation of the House of Commons Committee, 2008, paragraphs 1, 2, 14 and 45).

As a result, the Commons agreed on 12 November 2008 to a temporary Standing Order establishing, from 1 January 2009 until the end of the Parliament (May 2010), select committees for the East Midlands, East of England, North East, North West, South East, South West, West Midlands and Yorkshire and the Humber regions. The Committees were appointed to 'examine regional strategies and the work of regional bodies [i.e. Regional Development Agencies]' and could invite MPs (who were not committee members), and 'specified elected councillors' from the regions in question to attend and participate in its proceedings (albeit they could not move motions or amendments) (HC Deb 12 November 2008, 
vol. 499 c851). In June 2009, the House voted to appoint a select committee for London; unlike the other regional select committees, the existence of a devolved tier of government meant that this committee's remit also covered the Government's relationship with the Greater London Authority as well as its regional policies (HC Deb 25 June 2009, vol. 494 c969).

Boycotted by the Conservatives and Liberal Democrats and criticised for the 'barely visible' nature of their work, the nine regional select committees enjoyed a fleeting existence: the temporary standing order providing for their existence was not renewed by the House of Commons after the 2010 General Election (Pearce and Ayres, 2012, p. 19; Sandford, 2013, p. 11).

\section{Conclusion: territorial select committees, $\mathbf{4 0}$ years on}

As Benton and Russell have noted, since the creation of departmental select committees in 1979, these bodies 'have considerably developed their role in scrutinising the work of government ... have become better established, gained resources ... and attracted increasing media attention' (Benton and Russell, 2013, p. 773). It is no surprise, then, that since the territorial select committees have also been subjected to a process of evolution, particularly in terms of their respective post1998 remits.

The different timings of establishment, the asymmetric levels of (in)stability in the various devolution dispensations, and prolonged suspensions of devolution in Northern Ireland, have had an impact on the role of the respective territorial select committees.

In Scotland, the SAC's role was stable and predictable for most of the first decade of devolution, a reflection of the consistency in Scotland's devolution settlement from 1998 until the SNP entered government at Holyrood, first as a minority in 2007 and then with a majority after 2011. The SNP's election victories provided the means and motive for the SAC to play a more assertive role, particularly during the 2010-2015 Parliament and in the run-up to the 2014 independence referendum. While the Scotland Act 2016 has extended devolved competence over tax and, for the first time, welfare, these areas also mark a significant increase in co-dependency between Scottish and UK Governments with both sets of governments and parliaments sharing responsibilities in these fields. It is noteworthy that SAC and the Scottish Parliament's Social Security Committees held 'joint' evidence sessions as part of SAC's inquiry into intergovernmental cooperation on social security.

The WAC's remit and role, on the other hand, has evolved continuously since 1999, reflecting the ever-changing nature of Wales's devolution process. The Government of Wales Act 1998 gave way, in relatively short time, to the Government of Wales Act 2006, which, itself, contained two very different models 
of legislative devolution, the more complete version of which was activated in 2011. This instability, alongside the less clearly defined boundaries between devolved and reserved powers, has meant that the WAC's scope for influence has ebbed and flowed considerably post-devolution, arguably peaking during the 2005-2010 Parliament. While the Wales Act 2017 marks a notable increase in the NAfW's competence and puts Welsh devolution onto a 'reserved powers' footing for the first time, the NAfW and Welsh Government still enjoy less competence than their Scottish counterparts and question marks remain about the clarity of the Welsh devolution boundary.

Late to the departmental select committee party, the NIAC has seen its role shift even more markedly than the WAC's in response to the turbulent dynamics of Northern Irish politics. The return to direct rule between 2002 and 2007 offered the potential for a substantial increase in its workload (Birrell, 2009, pp. 57-60), and while the collapse of power-sharing in 2017 has not resulted in a return to direct rule, the UK's withdrawal from the European Union, and its particular implications for Northern Ireland, has seen the NIAC conduct several inquiries assessing the impact of Brexit on key sectors such as agriculture and fisheries as well as on the land border between Northern Ireland and the Republic of Ireland.

Brexit may be an opportune note on which to close. As has been argued in this article, the role and remit of the Scottish, Welsh and Northern Irish select committees has been shaped by developments in the UK's territorial constitution and the asymmetric nature of these changes. Brexit represents a significant challenge to the UK's constitution more generally and its territorial constitution specifically. Brexit will represent a significant increase in the number of policy areas where responsibility is held concurrently between the UK and devolved administrations and, as a result, has prompted considerable discussion about the establishment of 'common frameworks' for the management of relevant policy areas. These frameworks could offer a potentially important opportunity for interparliamentary relations in the UK.

The lack of effective and well-functioning arrangements for interparliamentary cooperation in the UK in the context of devolution has been lamented in a series of reports from commissions and committees over the last 20 years. Brexit, and the tectonic shift it could cause, may be the spur the territorial select committees need to re-energise inter-parliamentary cooperation and the scrutiny of intergovernmental action.

\section{Acknowledgement}

The authors would like to thank Paul Evans, the Clerk of Committees, for his helpful comments and suggestions on an earlier draft of this article. 


\section{Conflict of Interest}

The authors have no conflicts of interest to report.

\section{References}

Aylett, P. J. (2015) 'Thirty Years of Reform: House of Commons Select Committees, 1960-1990', Unpublished PhD Thesis, Queen Mary, University of London.

Barry Jones, J. (1985) 'The Welsh Affairs Committee'. In Drewry, G. (ed.) The New Select Committees: A Study of the 1979 Reforms, Oxford, Oxford University Press, pp. 289-304.

Barry Jones, J. and Wilford, R. A. (1986) Parliament and Territoriality: The Committee on Welsh Affairs 1979-1983, Cardiff, University of Wales Press.

Benton, M. and Russell, M. (2013) 'Assessing the Impact of Parliamentary Oversight Committees: The Select Committees in the British House of Commons', Parliamentary Affairs, 66, 772-797.

Berridge, J. S. and Kellas, J. (1973) 'The Mechanism of Scottish Government' in Commission on the Constitution', Research Papers 5: Aspects of Parliamentary Reform, London, HMSO.

Birrell, D. (2009) Direct Rule and the Governance of Northern Ireland, Manchester, Manchester University Press.

Burns, J. H. (1960, October) 'The Scottish Committees of the House of Commons, 1948-59’, Political Studies, 8, 272-296.

Davies, J. (2007) A History of Wales, London, Penguin.

Dewar, D. (1980) 'The Select Committee on Scottish Affairs'. In Drucker, H. M. and Drucker, N. L. (eds) The Scottish Government Yearbook 1981, Edinburgh, Paul Harris Publishing, pp. 9-25.

Drucker, H. M. and Kellas, J. G. (1985) 'The Scottish Affairs Committee'. In Drewry, G. (ed.) The New Select Committees: A Study of the 1979 Reforms, Oxford, Oxford University Press, pp. 223-238.

Edwards, G. E. (1971) 'The Scottish Grand Committee, 1958 to 1970', Parliamentary Affairs, 25, 303-325.

Evans, A. (2019) 'Inter-Parliamentary Relations in the United Kingdom: Devolution's Undiscovered Country', Parliaments, Estates and Representation, 39, 98-112.

Gardham, M. (2011, 26 October) 'SNP MP Quits Parliament Committee amid Claims Labour Chairman Threatened Her with “A Doing”, Daily Record.

Griffith, W. (2006) 'Welsh National Identity and Governance, 1918-45'. In Tanner, D. et al. (eds) Debating Nationhood and Governance in Britain, 1885-1945, Manchester, Manchester University Press, pp. 89-117.

Griffiths, S. and Evans, P. (2013) 'Constitution by Committee? Legislative Competence Orders under the Government of Wales Act (2007-11)', Parliamentary Affairs, 66, 480-510. 
Hadfield, B. (1981) 'Committees of the House of Commons and Northern Ireland Affairs', Northern Ireland Legal Quarterly, 32, 199-235.

Hazell, R. (ed.) (1999) Constitutional Futures: A History of the Next Ten Years, Oxford, Oxford University Press.

Jones, J. G. (1990) 'Alfred Thomas's National Institutions (Wales) Bills of 1891-92', Welsh History Review, 15, 218-239.

Mackintosh, J. P. (1970) Specialist Committees in the House of Commons: Have They Failed?, Edinburgh, Edinburgh University.

Masterman, R. and Hazell, R. (2001) 'Devolution and Westminster'. In Trench, A. (ed.) The State of the Nations 2001: The Second Year of Devolution in the United Kingdom, The Constitution Unit, Thorverton, Imprint Academic, pp. 197-224.

McConnell, A. and Pyper, R. (1994) 'A Committee Again: The First Year of the Revived Select Committee on Scottish Affairs', Scottish Affairs, 7, 15-31.

McConnell, A. and Pyper, R. (1996) 'The Select Committee on Scottish Affairs: Emerging Themes and Issues', Scottish Affairs, 15, 17-31.

Mitchell, J. (2014) The Scottish Question, Oxford, Oxford University Press.

Modernisation of the House of Commons Committee (2008) Regional Accountability, London, HC 282.

Osborne, R. (2002) 'Making a Difference: The Role of Statutory Committees in the Northern Ireland Assembly', Public Administration, 80, 283-299.

Pearce, G. and Ayres, S. (2012) 'Back to the Local? Recalibrating the Regional Tier of Governance in England', Regional \& Federal Studies, 22, 1-24.

Procedure Committee (1959) Report from the Select Committee on Procedure: Together with the Proceedings of the Committee, Minutes of Evidence and Appendices, London, HC 92-I.

Procedure Committee (1978) Report from the Select Committee on Procedure: Together with the Proceedings of the Committee, Minutes of Evidence and Appendices, London, HC 588-I.

Rawlings, R. (2003) Delineating Wales: Constitutional, Legal and Administrative Aspects of National Devolution, Cardiff, University of Wales Press.

Sandford, M. (2013, March 27) 'The Abolition of Regional Government', House of Commons Library Standard Note: SN/PC/05842.

Scottish Affairs Committee (1998) 'The Operation of Multi-Level Democracy', 2nd report, London, HC 460, December 1998.

Scottish Affairs Committee (2006) 'The Sewel Convention: the Westminster Perspective', 4th report, London, HC 983.

Torrance, D. (2006) The Scottish Secretaries, Edinburgh, Birlinn.

Torrance, D. (2010) Salmond: Against the Odds, Edinburgh, Birlinn. 
Trench, A. (n.d.) 'The Sewel Convention, Devolution Matters', accessed at https://devolu tionmatters.wordpress.com/the-sewel-convention/ on 26 June 2019.

Welsh Affairs Committee (WAC) (2000) First Special Report: The Work of the Committee since Devolution, London, HC 81.

Wilford, R. and Elliott, S. (1999) 'Small Earthquake in Chile: The First Northern Ireland Affairs Select Committee', Irish Political Studies, 14, 23-42. 